\title{
ERG Teorisi ve Hedonik Tüketim Bağlamında Iphone 11’in Tanıtımının İncelenmesi
}

* Doktora Öğrencisi, İstanbul Üniversitesi, rdvnonr@gmail.com Orcid ID: 0000-0001-8200-0618

\section{Gönderilme/ Received} 09.11.2021

Kabul Tarihi/ Accepted 15.11.2021

Yayın Tarihi/Published 17.11.2021
$\ddot{O} z$

Tüm sosyal bilimlerin önemli araştırma konularından olan insan ve toplum Sanayi Devrimi ve Kentleşme süreci devamında kitle kültürünün de etkisiyle daha da karmaşık ve önemli bir hal almıştır. Modern toplum yapısının oluşmasıyla birlikte birey üzerindeki incelemeler sosyal bilimler için önem kazanmıştır. Ayrıca Sanayi Devrimiyle birlikte gelişen endüstriyel yapı beraberinde iş alanında büyük gelişmeler sağlamıştır. $\mathrm{Bu}$ gelişmeler doğrultusunda bireylerin tüketiciye ve çalışan bireye evrilmesi, üreticiler bireylerden hem tüketici hem de çalışan olarak maksimum fayda sağlaması amacıyla temel psikolojik kavramların gelişmesini ve önem kazanmasına sebep olmuştur. Bu bağlamda insanı motive eden kaynaklar ve motivasyon en önemli araştırma alanlarından biri haline gelmiştir.

Tüketim kültürünün, tüketimi ön plana koyan ve bireyin tüm yaşam alanlarını tüketimle bağdaştırmalarını sağlayan bir kavram olarak sembolik tüketimi ön plana çıkarmasıyla birlikte bireylerin hedonik duygularına yönlendirilmiş bir tüketim algısı ortaya çıkmıştır. Tüketim kültüründe, hedonik tüketim kapsamında stratejiler geliştirilebilmesi için markaların imaj, bilinirlik, marka sadakati gibi kavramlara ve sembolik öğelere yer vermesi gerekmektedir. Bu sembolik öğelerin, tüketicilerin satın alma süreçlerine etki etmesi için tüketicilerin sembolik öğeleri ihtiyaç dahilinde görmesiyle ilgilidir. İhtiyaç - Kapsam Teorilerinden biri olan Clayton Alderfer'in ERG Teorisi, Abraham Maslow'un İhtiyaçlar Hiyerarşisi Kuramı'nı geliştirmiş ve bireyin ihtiyacının motivasyon kaynaklarının saptanması noktasında önemli bulgular eklemiştir. Bu bulgularla birlikte hedonik tüketimin etki ettiği bir alan olarak marka iletişim çalışmalarının ERG Teorisine göre değerlendirilmesi noktasında Apple Iphone markasının 11 model telefonunun tanitımı sürecinde Apple Türkiye Web Sitesi bölümündeki tanıtımları incelenmiş ve hedonik tüketimin bireyin hangi ihtiyaçlarına etki ettiğinin saptanması içerik analizi yöntemiyle ortaya konulmuştur.

Anahtar Kelimeler: Motivasyon, İhtiyaçlar, ERG Teorisi, Hedonik Tüketim, Iphone 


\section{Examination of Iphone 11's Promotion in the Context of ERG Theory and Hedonic Consumption}

\section{iD Rıdvan ÖNER*}

* Phd Student, İstanbul University, rdvnonr@gmail.com Orcid ID: 0000-0001-8200-0618

Gönderilme/ Received 09.11.2021

Kabul Tarihi/ Accepted 15.11.2021

Yayın Tarihi/Published 17.11.2021

\begin{abstract}
Human and society, which is one of the important research subjects of all social sciences, has become more complex and important with the effect of mass culture in the continuation of Industrial Revolution and Urbanization process. With the formation of modern social structure, studies on the individual gained importance for the social sciences. In addition, the industrial structure that developed with the Industrial Revolution has led to great improvements in business. With these developments, the evolution of individuals to consumers and working individuals has led to the development of basic psychological concepts and gaining importance in order to provide maximum benefits from individuals as both consumers and employees. In this context, the resources which motivates humans and the motivation itself have become one of the most important research areas. With the consumption culture emphasizing it as a concept which puts consumption at the forefront and enables the individual to reconcile all living spaces with the concept, a perception of consumption directed towards individuals' hedonic feelings has emerged. In order to develop strategies within the context of hedonic consumption, brands need to include concepts and symbolic elements such as image, awareness, brand loyalty. This relates to the fact that consumers see symbolic elements in need so that symbolic elements affect consumers' purchasing processes. Clayton Alderfer's ERG Theory, one of the Needs-Scope Theories, developed Abraham Maslow's Theory of Needs Hierarchy and added important findings to identify the motivation sources of the individual's needs. With these findings, in the process of evaluating brand communication activities according to ERG Theory as an area affected by hedonic consumption, Apple Iphone 11 model phone's publicity in Apple Turkey's Web Site been studied and the content analysis method was determined by the requirements of hedonic consumption.
\end{abstract}

Keywords: Motivation, Needs, ERG Theory, Hedonic Consumption, Iphone 


\section{Giriş}

İnsanların doğumundan ölümüne kadar geçen sürede sürekli veya geçici ihtiyaçları bulunmaktadır. Bu ihtiyaçların insanlarda oluşturduğu motivasyon ise özellikle psikoloji alanında incelenmekte ve diğer sosyal bilimlerin (iktisat, iletişim, sosyoloji vb.) çalışma alanı için önemli bir yer tutmaktadır.

Psikoloji alanında güdü, motiv gibi kavramların motivasyona etkileriyle birlikte motivasyon kavramı farklı sosyal bilimciler tarafindan teori haline getirilmişlerdir. $\mathrm{Bu}$ çalışmada motivasyon ve ihtiyaçlarla ilgili olan Clayton Alderfer'in ERG Teorisi incelenerek bireylerin satın alma davranışlarının hedonik tüketimle bağlamı incelenecektir. Çalışma içerisinde Alderfer’in ERG Teorisinin çıkış noktası olan Abraham Maslow'un İhtiyaçlar Hiyerarşisi kuramı da incelenecektir. Kapsam teorileri kapsamında günümüze kadar gelmiş en önemli kuramlardan biri olarak görülen Maslow'un İhtiyaçlar Hiyerarşisi Kuramı, Alderfer tarafından yeniden değerlendirilmiş ve kuram ERG Teorisi kapsamında geliştirilmiştir.

Çalı̧̧manın bağlam konusu olan hedonik tüketim öğesi tüketim kültürü içinde incelenerek bir tüketici için önemi, sembolik değerlerden oluşan sürecin temel ihtiyaç olarak görülmesi gibi sebeplerin ihtiyaç bağlamında araştırılması da gerekmektedir. Bu yapının tüketici etkileşimi bağlamında incelenmesi için Iphone markasının 11 modelinin tanıtımında yer alan ifadeler ve motivasyon öğeleri ERG teorisindeki ihtiyaçlar sinıflandırmaları olan Varolma, İlişkilendirme ve Gelişme kavramları bakımından ele alınacaktır.

\section{Motivasyon ve Motivasyon Kaynakları}

İnsanların davranışlarının şekillenmesi ve bu davranışlara göre hareket etmesinin en önemli etkenlerinden biri motivasyondur. 19 yy.'da sosyal bilimlerin gelişmesiyle birlikte insanların bireysel ve sosyal hareketlerinin incelenmesi amacıyla motivasyonun açıklandığı ve kavramlaştırıldığı ilk çalışmalar görülmektedir. Bununla birlikte motivasyon, insan davranışlarını açıklamak isteyen veya davranışlara yön vermek isteyen tüm bilimlerin veya organizasyonların başvuracağı en önemli konulardan biridir (Taşdemir, 2013, s. 10). Bu bağlamda endüstri, sosyal bilimler, eğitim, pazarlama ve siyaset gibi pek çok alanda motivasyonla ilgili çalışmalara rastlanması mümkündür. Motivasyon genel anlamıla, insan organizmasını davranışa iten, bu davranışların etki düzeyini belirleyen, davranışa belli bir yön veren ve devamını sağlayan işleyiş mekanizmalarını içermektedir (Arık, 1996, s. 15). Bu mekanizmalar biyolojik ve sosyal motivler olarak ayrllabilmektedir.

Motivasyon kökeni olarak Latince "motus" kelimesinden gelmektedir (Taşdemir, 2013, s. 5). Hareket etmek anlamındaki 'movore' kelimesinden türetilen ve batı dillerinde "motif-ive" ve "motivation" şeklinde yazllan motivasyonun sözlüklerde; güdü, saik, sebep, gerekçe, örge, güdüleme, saiklenme, nedenlilik, gerekçelendirme kelimeleriyle karşılanmaktadır (Anık, 2000, s. 77). Motivasyon kelimesinin kökündeki motiv; kişiyi harekete geçmeye zorlayan bir gereksinim olarak tanımlanmaktadır (Karadoğan Doruk, 2015, s. 103).

Motivasyon, insanların belirli bir amacı gerçekleştirmeleri için harekete geçmesini sağlayan bir süreçtir (Alan, 2006, s. 20). Popüler anlamlarıyla motiv ve 
motivasyon kavramları, bir davranışın sebebini ve kişiyi harekete geçiren neden olarak gösterilmektedir (Anık, 2000, s. 78). İhtiyaçlar, istekler ve dürtülerden kaynaklanarak motive olan kişinin davranışlarını etkileyen veya değişmesine yol açan üç duygu vardır: korku, görev olarak hissetme, sevgi.

- Korkudan dolayı motive olunduğunda kişi bunu mecburiyetten yapar,

- Görev olarak hissedilen motivasyon sürecinde kişinin görevi yapma gerekliliği ortaya çıkar,

- Sevgiden dolayı motive olunduğunda ise kişi bunu istediği için yapar (Us, 2007, s. 9-10).

Motivasyon tanımlarında, motivasyon sürecinin üç temel özelliğe sahip olduğu belirtilmektedir. Bunlar; insan davranışında neyin harekete geçiren etken olduğu, bu davranışı neyin kanalize ettiği veya yönlendirdiği ve bu hareketin nasıl korunduğu ya da süreklilik kazandığıdır (Anık, 2000, s. 80).

Motivasyonun incelenmesi sürecinde ihtiyaç, güdü - güdülenme, davranış gibi kavramların konu içinde oldukça önemli bir yer aldığı görülmektedir. Bu kavramlar birbirine bağlantılı olarak ilerler ve davranışı ortaya çıkarır. Özellikle motivasyonla bağlantılı konuların içeriğinde yer alan güdü; bilinçli veya bilinçsiz olarak davranışı doğuran, davranışının sürekliliğini sağlayıp davranışa yön veren herhangi bir güç olarak tanımlandırılabilir (Türk Dil Kurumu Sözlükleri, 2020). Insanların tatmin edilmemiş ihtiyaçlarının uyarılmasıyla kişiyi davranışa iten güç olan güdü bir amaç veya ihtiyaç için davranışa geçilmesini sağlamaktadır (Alan, 2006, s. 20).

Motivasyonla birlikte kişinin hissettiği fizyolojik, psikolojik veya sosyal eksiklikler olan ihtiyaç kavramı bireyi güdüleyen en önemli kaynaklardan biri olarak görülmektedir (Karadoğan Doruk, 2015, s. 170).

İhtiyaç, bedensel veya dokusal yoksunlukların (açlık, susuzluk, acının doğurduğu dengesizlik, cinsel hormonların kanda birikmesiyle doğan gerginlik) yol açtığı fizyolojik bir organizma halini, dürtü ise bu fizyolojik halin bir sonucu olarak ortaya çıkan psikolojik durumu ifade etmektedir. Dürtü ve ihtiyaç arasında sıkı bir ilişki olmasına rağmen ihtiyaç her zaman aynı şiddette dürtülere sebep olmaz (Arık, 1996, s. 121). İhtiyacın her zaman aynı şiddette dürtüye sebebiyet vermemesi konusu ihtiyaç kuramları içindeki kavramlarda detaylı olarak açıklanmaktadır.

Motivasyon ve motivasyonla ilgili tanımlar incelendiğinde, motivasyonun temelini oluşturan üç ana faktörün;

- Insan davranışını tetikleme

- Davranışı yönlendirme

- Davranışın sürdürülmesi olduğu ortaya çıkmaktadır (Alan, 2006, s. 19).

Çalışmanın temelinde yer alan, kişinin bir davranışa yönlendirilmesiyle alakalı olarak ihtiyaç kuramları ise, çeşitli güçlerin çevreyle etkileşimi sonucu davranışa nasıl sevk edildiğiyle ilgili tanımlamalar içermektedir. Bu bağlamda incelenecek olan Alderfer'in ERG Teorisi, ihtiyaç kuramları çerçevesindeki içerik veya kapsam teorileri içinde yer almaktadır. İçerik teorileri, kişileri nelerin motive ettiği konusunu ele almaktadır. İçerik teorileri insanları harekete geçiren 
gücün ne olduğı ve insanların tatmin etmeye çalıştıkları ne tür ihtiyaçları oldukları ve bunu nelerin motive ettiğini incelemektedir (Taşdemir, 2013, s. 23).

\section{Maslow İhtiyaçlar Hiyerarşisi Teorisi ve Clayton Alderfer'in ERG (VİG) Teorisi}

\subsection{Maslow'un İhtiyaçlar Hiyerarşisi Modeli}

Alderfer'in ERG Teorisinin çıkış noktası olarak değerlendirilen Maslow'un ihtiyaçlar hiyerarşisi kuramı, ihtiyaç kuramları arasında en çok bilinenidir (Karadoğan Doruk, 2015, s. 178). İhtiyaçlar Hiyerarşisi kuraminda iki ana varsayımı vardır. Bu varsayımlardan birincisi; kişinin gösterdiği her davranışın, kişinin sahip olduğu belirli ihtiyaçları gidermeye yönelik olduğu ikincisi ise ihtiyaçların sırası ile ilgilidir. Bu yaklaşıma göre ihtiyaçlar belli bir hiyerarşiye sahiptir; alt kademelerde bulunan ihtiyaçlar giderilmeden, üst kademelerdeki ihtiyaçlar kişiyi davranışa sevk etmemektedir (Koçel, 2010, s. 623). Maslow'un bu kuramı çoğu araştırma için ilk çıkış noktası olma özelliğini korurken kişinin ihtiyacı gidermeye yönelik bir varlık olduğu ve bu ihtiyaçların belli bir hiyerarşiye sahip olması özelliği Maslow tarafından yoksunluk (debrivation) ve çekicilik (gratification) kavramlarıyla açıklanmaktadır (Karadoğan Doruk, 2015, s. 173). $\mathrm{Bu}$ iki kavram günümüzde ürün pazarlama ve hedonik tüketim için de önemli kavramlardır.

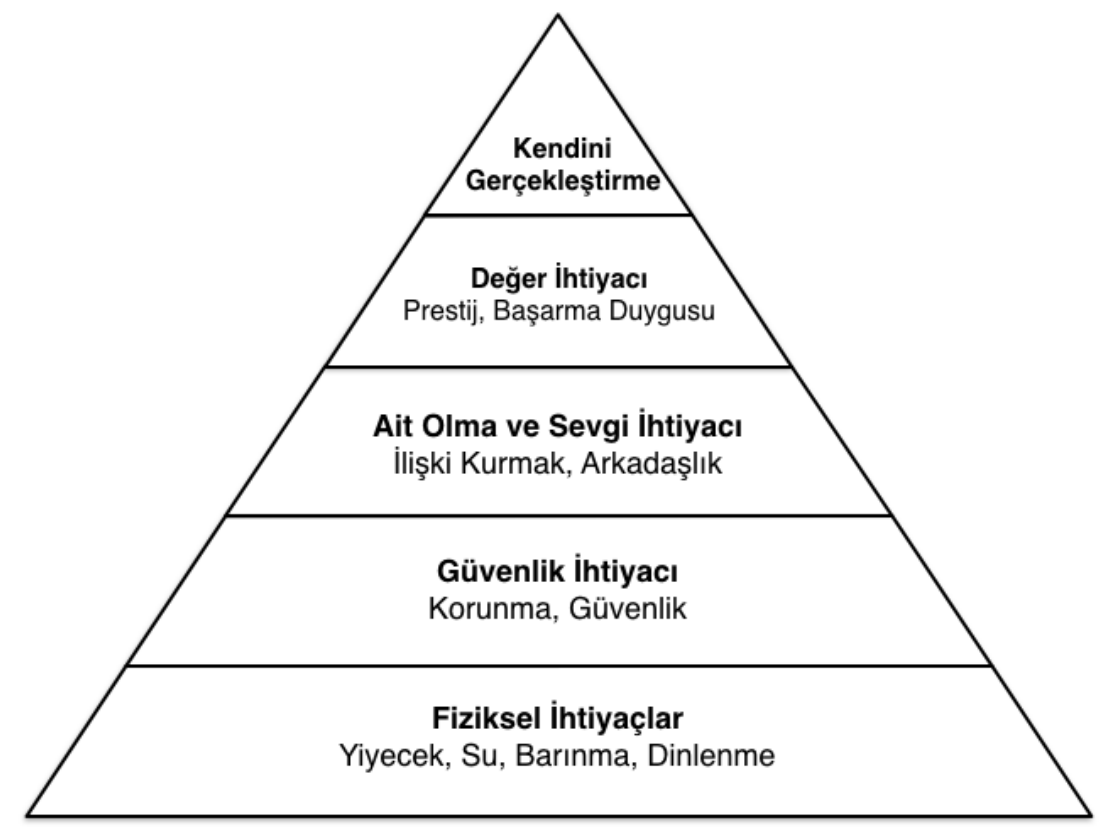

Tablo 1: Maslow'un İhtiyaçlar Hiyerarşisi Piramidi (Gülbay, 2016)

Tabloda belirtilen temel ihtiyaçlar; fizyolojik, güvenlik, sevgi, saygınlık ve kendini gerçekleştirme ihtiyaçlarıdır. $\mathrm{Bu}$ temel ihtiyaçların alttan üste doğru olmak üzere bir düzen içinde oldukları ve alt basamaktaki ihtiyacın karşılandıktan sonra bir üst basamaktaki ihtiyacın davranışı etkilemeye başladığı görülmektedir (Ulukuş, 2016, s. 249). Kurama göre bir ihtiyacın ortaya çıkması bunun altındaki ihtiyacın belirli düzeyde tatmin edilmesiyle alakalıdır. Bir alt düzeydeki ihtiyaç belirli düzeyde tatmin edilmediği sürece üst düzeydeki ihtiyaçlar kendilerini gösteremez, harekete geçirecek motivasyon ortamını sağlayamaz (Alan, 2006, s. 26). Bireyin fiziksel ihtiyaçlarını tatmini sonrasında, 
sonradan öğrenilmiş olarak nitelendirilebilecek ve görece aile ve kültürün de etkisinin olduğu (Alderfer ERG teorisinde bu kültürün çevresel etkilerin olduğundan bahsetmektedir.) güvenlik ihtiyaçları kapsamında fiziki, ekonomik, sosyal ve siyasal açıdan güvenli bir ortam oluşturma ihtiyacı duyulmaktadır (Taşdemir, 2013, s. 25). Bu iki ihtiyacın tatmin edilmesiyle birlikte bireyin ait olma ve sevgi ihtiyacı, arkadaşlık, sevgili olma, sevme - sevilme, bir gruba veya zümreye dahil olma isteğini ortaya çıkaracak ve birey bunun için güdülenecektir (Karadoğan Doruk, 2015, s. 175). İlk üç ihtiyaçtan sonra tüketim kültürünün de bireyi yönlendirici sembolik ve hedonik tüketim öğelerini ilgilendiren değer ve kendini gerçekleştirme ihtiyacının ilk basamağı olan değer ve saygı görme iki grupta ele alınabilmektedir. Değer görme gereksinimlerinin ilki; bireyin çevresi nezdinde güç, başarı, yeterlilik, ustalık ve beceri göstererek kendini ispat etme çabası, güvenilir olduğunu gösterme arzusu olarak ifade edilirken, ikincisi ise; prestij, statü, üstünlük, tanınma, değerli olma, saygınlık ya da takdir için duyulan arzu şeklinde yorumlanabilir (Taşdemir, 2013, s. 27). Değer ihtiyacı kapsamında nitelikler ikna bağlamında değerlendirilmesi gereken önemli kavramları içermektedir. Piramidin en üstünde yer alan kendini gerçekleştirme ihtiyacı ise kişinin gizli yetenek ve potansiyelinin farkında olması ve bunları uygulama, kullanma arzusu ile ilgili bir ihtiyaçtır (Anık, 2000, s. 100). Genel olarak, bu kavramdan anlaşılan, insanın kendi yeteneklerinin gelişmesi ve yaratıcılığının farkına varmasıdır (Alan, 2006, s. 32).

\subsection{Alderfer ERG Teorisi}

Hedonik tüketim bağlamında tüketicinin ihtiyaçlarının belirlenmesi ve saptanmasının incelendiği bu çalışmanın teorik altyapısını oluşturan ERG teorisi Clayton Alderfer tarafından ortaya atılmıştır. Alderfer, Maslow'un ihtiyaçlar hiyerarşisi kuramını; eleştiriler, yeni bulgu ve yaklaşımlar doğrultusunda yeniden işlemiştir (Anık, 2000, s. 102). Alderfer ERG teorisinde ihtiyaçları Varoluş (Existence), İlişki kurma (Relatedness) ve Gelişme (Growth) kategorileri altında incelemiştir (Karadoğan Doruk, 2015, s. 181). Genellikle iş alanında çalışanların motivasyonun incelenmesinde kullanılan ERG Teorisi sosyolojik, psikolojik ve örgütsel alanlar olmak üzere geniş bir yelpazeyle ilgisi bulunmaktadır (Caulton, 2012, s. 2). Kültürel uygulamalar açısından da incelenen ERG Teorisini Chang ve Yuan (2008), müşterilerin web tabanlı bir projeyle nasıl etkileşime gireceğini belirlemek için Markov Zinciri modeliyle birleştirerek, birbiriyle ilişkili bir dizi noktaya dayanan sonuçları tahmin eden sentetik bir model oluşturmuşlardır (Caulton, 2012, s. 4). Bu çalışmada da teori, tüketicilerin satın alma davranışlarının motivasyon etkileri altında hedonizm ve ihtiyaçlar ile birlikte incelenmiştir. 


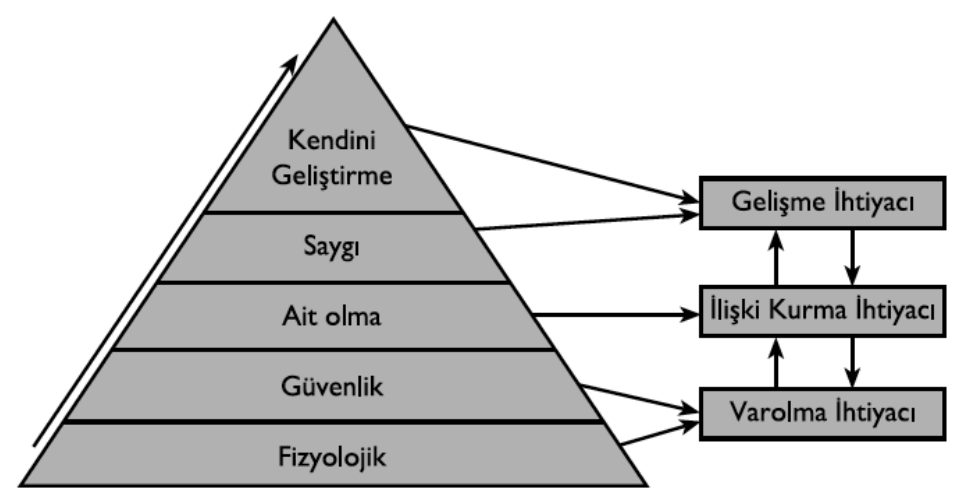

Tablo 2: Maslow'un İhtiyaçlar Hiyerarşisi Piramidi ve Alderfer'in ERG Teorisi (Ergun Özler, 2013, s. 146)

Maslow'un İhtiyaçlar Hiyerarşisi kuramıyla Alderfer'in ERG teorisi arasındaki farklılıklardan en önemlisi Maslow'un belirlediği, beş basamağın üçe indirilmiş olmasıdır. Maslow'un beş basamaklı yapısına karşı, Alderfer birçok ihtiyacın aynı anda ortaya çıkabileceğini ve kişiyi güdüleyebileceğini öne sürmüştür (Karadoğan Doruk, 2015, s. 181). Alderfer'e göre ihtiyaçlar, Maslow'daki gibi belirli hiyerarşik yapıyı izleyerek ortaya çıkmazlar. Bu teoride ihtiyaçlar arasındaki hiyerarşik sıraya daha az vurgu yapılırken birden fazla ihtiyacın aynı anda karşılanabileceği belirtilmektedir. Örneğin; kişi hem ilişki kurma hem de gelişme ihtiyacını aynı anda hissedebilir (Ergun Özler, 2013, s. 145). Postmodernizm ve tüketim kültürü ile ilgili çalışmalarda Featherstone (1996) ve Baudrillard (2015) kültürler arasında sınırların belirsizleştiği üzerine yoğunlaşmıştır. Postmodernizmin genel yapısı itibariyle modernizme göre daha esnek ve karmaşık bir yapıda olması tüketim kültürü bağlamında da farklı yapılara sebebiyet vermektedir. Yaşam Tarzı kavramının bu dönemde etkin olmasıyla birlikte bir tüketici için kendini gerçekleştirme ve gelişme ihtiyacı diğer alt ihtiyaçlardan veya varoluşsal ve ilişkisel ihtiyaçlardan daha fazla ön planda olabilir.

Maslow, alt seviyedeki bir ihtiyaç tatmin edildiğinde üst seviyeye geçildiğini, ihtiyaçlar tatmin edildikçe hiyerarşinin üst basamaklarına doğru ilerleme olduğunu öngörmektedir. Oysa Alderfer'in modelinde ihtiyaçların tatmini söz konusu olabildiği gibi ihtiyaçların tatmininde karşlaşılan güçlükler bireyde içe kapanma ve geri çekilme etkisi de yaratabilmektedir (Anık, 2000, s. 102). Daha yüksek bir ihtiyacın karşılanması için bir girişim hayal kırıklığına uğradığında, bireysel kaygı sebebiyle karşılanmış ihtiyaçlara doğru gerileme olduğu görülmektedir (Efere, 2005, s. 11). Alderfer'i Maslow'dan ayıran diğer bir fark ise Maslow'un hiyerarşisinde yer almayan merak ve öğrenme ihtiyacıdır. Bu iki ihtiyaç güzele yönelme ve çirkinden uzaklaşmayı anlatan bireyin kognitif ve estetik ihtiyaçlarıdır (Anık, 2000, s. 103).

Alderfer'in ERG (VİG) teorisinde varolma ihtiyacı Maslow'un piramidine göre fizyolojik ve güvenlik ihtiyaçları, ilişki kurma ihtiyacı sosyal ihtiyaçlar ve saygınlık ihtiyacını, gelişme ihtiyacı ise saygı görme ve kendini gerçekleştirme ihtiyacını karşılamaktadır (Taşdemir, 2013, s. 34). Varoluşsal ihtiyaçlar, kişinin varlığını sürdürme ve koruma süreciyle alakalıdır (Karadoğan Doruk, 2015, s. 182). İlişki kurma ise daha duygusal durumları ifade eder. İlişki kurma süreci, 
düşüncelerini ve duygularını karşılıklı olarak değiştiren iki veya daha fazla kişiden oluşur (Alderfer, 1967, s. 441). Gelişme süreci ise kişinin potansiyel veya gerçek kapasitelerinde bulunan sorunların çözümlerini ifade etmektedir. Kişinin yeteneklerini entegre etmek ve farklılaştırmak gelişme ihtiyaçlarını karşlama sürecidir. Beceri ve yetenekleri kullanmak bu çalışmada dikkate alınan gelişme ihtiyacıdır (Alderfer, 1967, s. 441).

Alderfer'in kuramı insan çevre ilişkilerini içermesinden ve ihtiyaçların çevredeki duruma göre değişik biçimler aldığını belirtmesinden dolayı önemlidir (Anık, 2000, s. 103). Buna ilaveten bazı kültürlere göre temel ihtiyaçların doyurulmadığı yerlerde sosyal ilişkilerin doyurulması ve önemi ön plana çıkabilmektedir (Karadoğan Doruk, 2015, s. 183). Bu noktada günümüzde sıkça rastlanan fiziksel ihtiyaçların tatmininden çok ilişkilendirme ve gelişme ihtiyaçlarının ön planda olması durumuna Iphone markasının yarattığı algı, tüketicinin markaya olan bakış açısı ve sadakati önemli bir örnektir.

\section{Tüketim Kültürü ve Hedonik Tüketim}

\subsection{Tüketim Kültürü}

Sanayi devrimiyle birlikte üretimin kolaylaşması ve modernizm ile birlikte bireye yönelik algının gelişmesi İkinci Dünya Savaşı'ndan sonra farklı bir noktaya evrilmiştir. Postmodernizmin kültürler arası sınırları silikleştirmesi beraberinde kitle kültüründe değişmelere sebebiyet vermiştir. Diğer taraftan kitle kültürünün tüketimi topluma empoze etmesi ve yaşam tarzlarının gerçekleştirilmesinin tüketime bağlı olduğu algısının oluşturulması ile birlikte tüketiciler ürün satın alma davranışlarına hedonik ve sembolik süreçler eklemiştir. Markaların da bu süreçte imajlarını geliştirmek ve tüketici nezdinde iyi bir konumlandırmaya sahip olmak amacıyla sembolik reklamlara yönelmesi tüketici algısında hedonik tüketimin önemli bir ihtiyaç haline dönüşmesini sağlamıştır.

'Tüketim kültürü teriminin kullanılması ürünler dünyasının ve bunların yapılanma ilkelerinin günümüz toplumunun anlaşılması açısından merkezi bir yer işgal ettiğinin vurgulanması anlamına gelir. Bu vurgu ikili bir odaklanmayı içerir: İktisadın kültürel boyutu üzerinde, maddi ürünlerin sadece faydalar olarak değil, aynı zamanda "iletişim vasıtaları" olarak da kültürel ürünlerin iktisadı üzerinde, hayat tarzları, kültürel ürünler ve metalar alanı içerisinde işleyen arz, talep, sermaye birikimi, rekabet ve tekelleşme gibi piyasa ilkeleri üzerinde odaklanmayı içerir." (Featherstone, 1996, s. 144).

Bu bağlamda tüketim kültürü, tüketicilerin çoğunluğunun yararcı olmayan statü arama, ilgi uyandırma, yenilik arama gibi özelliklerle öne çıkan ürün ve hizmetleri arzuladıkları ve bu arzularının peşine düşüp, arzu edilen nesneye sahipliğin sergilendiği bir kültür olarak tanımlanabilir (Uztuğ, 2005, s. 98). Tüketim kültürünün incelenmesi noktasında yaşam tarzı seçenekleri ile tüketim nesnelerinin simgesel değerinin artması üzerinde durulmaktadır (Lodziak, 2003, s. 17). Tüketim kültürü daha önce hiç görülmemiş bir şekilde insanların ihtiyaçlarını manipüle etmekte ve onları sürekli yeni tüketim ihtiyacı olduğuna inandırmaktadır. Tüketicinin eyleme geçebilmesi için de haz ve arzular ön plana 
çıkarılmakta ve reklamlarda ürün özelliklerinden ziyade bu algılara yer verilmektedir. Eylem sürecinin direk motivasyon ve ihtiyaçla ilgili süreçlere dahil olması da bu konunun psikoloji, motivasyon ve ihtiyaç kuramları çerçevesinde incelenmesini gerekli kılmaktadır.

\subsection{Hedonik Tüketim ve Hedonik Tüketimin ihtiyaca dönüşmesi}

Tüketim kültüründe sembolik tüketimin bir ihtiyaç haline dönüşmesi ihtiyaç kuramları dahilinde ele alınan ERG teorisinde ihtiyaçların aynı anda ortaya çıkması durumunu hatırlatmaktadır. Günümüzde çoğu birey varoluşsal ihtiyaç tatminlerini tamamlamadan direk gelişme ihtiyaçları içine dahil olabilmekte ve bu doğrultuda tüketim alışkanlıklarını geliştirebilmektedir. Çalışmadaki ikinci önemli kavram olan hedonik tüketimdeki hedonizm, günümüz motivasyon kuramlarının çoğunun başlangıcını oluşturmaktadır (Anık, 2000, s. 83)(Anık, 2000: 83). Hedonizm yunanca "hedon" haz kelimesinden türetilmiştir (Karadoğan Doruk, 2015, s. 110).

Hayatın esas gayesinin zevk olduğunu öngören hedonizme göre tercihler ve yönelimler bilinçlidir. Bu bilinçle hareket eden birey, olumlu sonuç doğuracak davranışlara en çok, olumsuz sonuç doğuracak davranışlara en az yönelmeyi hedeflemektedir (Anık, 2000, s. 83). Hazza yönelmenin ve acıdan kaçınmanın birey davranışının temel güdüleyici güçlerinden biri olması hedonizmin motivasyon kuramları bağlamında önemini de ortaya koymaktadır (Doruk, 2015: 11). Hedonizmi sistematik bir ahlak felsefesi halinde sunan Epikuros, hazzı etken edilgen ya da statik dinamik biçiminde ikiye ayırmaktadır. Dinamik haz, arzulanan sonucun elde edilmesi; statik haz, arzunun tatmin edilmesinden sonraki hazdır (Anık, 2000, s. 83)(Anık, 2000: 83). 18. ve 19. Yy'larda yeniden popülarite kazanan hedonizm özellikle Jeremy Bentham tarafından hedonik kavramıyla geliştirilmiştir (Anık, 2000, s. 83).

En önemli motivasyon kaynaklarından biri olan hedonizm hedonik tüketim bağlamında incelendiğinde, gerçeğin düş gücüne dayanarak yapılanmasına bağlı olduğu görülmektedir. Bu sebepten ötürü hedonik tüketim tüketicinin neyi gerçek olarak bildiğine değil, gerçeğin nasıl olmasını istediğine bağlıdır (Odabaşı, 2013, s. 116). Sözcükler, resimler, heykeller ve neonlar bir arada harmanlanır ve tersine hedonistik bir tüketim kültürü manzarası üretmek üzere simgeselcilik yeniden gündeme getirilir (Featherstone, 1996, s. 166). Satın almaya yol açan ya da açmayan tüketici motivasyonları, malların kimlik oluşturmadaki sembolik değeri bağlamında anlaşılmaktadır (Lodziak, 2003, s. 43).

İhtiyaçların hedonik tüketim bağlamındaki manipülasyonu genellikle, medyanın ve reklamcılığın tüketiciyi gerçekte ihtiyacı olmayan şeylere ihtiyaç duyar hale getirme gücü olarak algilanmaktadır (Lodziak, 2003, s. 40). Reklamdan alınabilecek bütün zevk tüketim beklentisidir; çünkü reklamın maddi olarak tüketiciye getirdiği şey budur (Williamson, 2001, s. 167). Tüketicilerin ürünü beğenip ve kendileriyle özdeşleştirmeleri; o ürünü yani markayı tekrar satın almasına sebebiyet vermektedir. Çünkü tüketiciler için, sahip oldukları ve sürekli aldıkları ürün markaları kendilerine prestij sağlamaktadır. Birçok tüketici için; Benetton giymek, BMW arabaya binmek, Rolex saat takmak bir ayrıcalık olarak görülmektedir (Ar, 2004, s. 7). Gelişen teknolojiyle birlikte ortaya çıkan yeni ürünlerde de (akıllı telefon, tablet bilgisayar ve teknolojik aksesuarlar) 
tüketiciler, kullandıkları markaların kendilerine prestij sağlandığına ayrıcalıklı olduğuna inandırılmaktadırlar.

$\mathrm{Bu}$ bağlamda hedonik tüketimin, tüketicilerin ürün kullanımından çoklu duyuşsal imajlarına, fantezilerine ve duygusal uyarımlarına atıfta bulunduğu görülmekte ve bu yapılanma içinde satın alma için güdülendikleri görülmektedir (Odabaşı, 2013, s. 115).

\section{Araştırma Yöntemi}

Tüketicilerin tüketim kültürü içinde maruz kaldıkları iletişim çalışmalarıyla birlikte temel tüketim sürecinden çok hedonik tüketim öğelerine önem verdikleri ve bu bağlamda yaşam tarzlarına uygun ürünleri satın almak amacıyla güdülendikleri görülmektedir Medyanın, bireyin isteğiyle veya medya etkisine istemsiz maruz kalmasından bağımsız bireylerin davranışları üzerinde motivasyonel bir güç olarak manipülatif etkilere sahip olduğu görülmektedir (Anık, 2000, s. 71). Araştırma kapsamında Iphone markasının 2019 yılında piyasaya sürdüğü 11 modelinin internet sitesindeki tanıtımı incelenerek içeriğinde sembolik öğelere odaklanılacaktır. Bu simgesel metin ve görsellerin tüketici bireyler üzerinde hangi ihtiyaç sürecine dahil edildiği ve ne yönde bir motivasyon oluşturabileceği ile ilgili bulguların saptanması amacıyla Clayton Alderfer'in ERG Teorisinden yararlanılacaktır.

Araştırma deseni olarak seçilen içerik analizi yöntemiyle Apple Türkiye internet sitesinin Iphone 11 bölümünde hangi öğelere ve motivasyonel öğelere yer verildiği incelenecektir. Sosyal bilimlerde önemli bir araştırma yöntemi olan İçerik analizi uygulamaları, günümüzde daha çok kitle iletişim araçlarının içerikleri, iletileri ile ilgili araştırmalarda kullanılmaktadır (Aziz, 2011, s. 129). İçerik analizi teknikleri, esas olarak üç tür ihtiyaç karşılar (Ghiglione ve Matalon 1978); Politik ve sosyal ihtiyaçlar, ekonomik ihtiyaçlar ve klinik ihtiyaçlar (Bilgin, 2006, s. 6). Bu bağlamda Iphone marka telefon ekonomik ve sosyal çerçevede değerlendirilecektir. İçerik analizinin kullanım alanlarında, hedonik tüketimi tanımlar bir şekilde; "günlük yaşamımızdaki eşyaların bir dil gibi işlediği, örneğin giysilerin bir mesaj olduğu, evimizin konuştuğu varsayımıyla eşyaların incelenmesi” gibi araştırmaların da yapıldığı belirtilmektedir (Bilgin, 2006, s. 10).

Üretim sürecindeki gelişmelerde Post - Fordist yapıyla birlikte farklı markaların ortaya çıkması ve tüketicilerin isteklerinin ve taleplerinin dikkate alınması sonucunda tüketim kültürünü kitle kültürü içinde önemli bir noktaya konumlandırılmıştır. Bu kültür içerisinde tüketicinin tüketimi haz öğesi olarak görmesi ve bununla birlikte hedonik tüketimin ihtiyaç dahilinde algılanması amacıyla markaların reklam ve diğer iletişim içeriklerinde bir sosyal süreç içinde bulunma, ürünün kişiye ayrıcalık kazandırması, ürünün kişinin hobi ve farklı isteklerine yönelik kullanımı gibi süreçler yansıtılmaktadır.

\section{ERG Teorisi ve Hedonik Tüketim Bağlamında Iphone 11'in Tanıtımının İncelenmesi}

Teknolojik gelişmeler doğrultusunda ortaya çıkan yeni cihazlar tüketicilerin temel ihtiyaçlarını karşılamakla birlikte hedonik tüketim ihtiyaçlarını harekete geçirecek çalışmalara da yer vermektedirler. Bunun öncelikli sebebi olarak bir ürünün birden fazla marka tarafindan oluşturulması 
ve bu sebepten ötürü markanın tüketici nezdinde vazgeçilemez bir konuma getirilmesinin sağlanmaya çalışılmasıdır. Bununla birlikte teknolojik gelişmelerin getirdiği kültürel değişimler de (sosyal medya platformları, çevrimiçi medyalar ve akıllı telefon uygulamaları vb.) bu süreci oldukça önemli bir şekilde etkilemektedir. Akıllı telefon alanında ilk tam dokunmatik ekranlı telefonu çıkaran Iphone bu alanda devrim niteliğinde bir çalışmaya imza atmıştır. Bu yenilikle birlikte Apple'ın marka geçmişinden gelen imajı Iphone'a yansitmayı başaran Iphone her yeni telefonunda tüketicinin sembolik ve hedonik algılarını etkileyecek reklam ve iletişim çalışmalarına da imza atmiştır.

Araştırma konusu olarak ele alınacak iPhone akıllı telefonları, Apple tarafindan tasarlanan ve üretilen multimedya ve internet özelliklerini destekleyen akıllı telefondur. Ilk modeli 29 Haziran 2007'de tanıtılmıştır (Vikipedi, 2021). Serinin 13. modeli olan Iphone 11, ise 10 Eylül 2019'da tanıtılmıştır (Vikipedi, 2021).

Araştırma deseninin bağımsız değişkeni olarak ele alınan Iphone 11 modeli, Apple Türkiye internet sitesi üzerinde tüketicilerin teknik detayları ve tanıtımını görmek amacıyla sunulmuştur. Bu bağlamda Iphone 11 modelinin görsel ve metinsel öğeleri İçerik analizinin Osgood (1959) tarafindan geliştirilen tekniği, olumsallık analizi tekniğiyle incelenecektir. Bu yöntemde, mesajdaki öğeler arasındaki ilişkiler incelenmektedir (Bilgin, 2006).

Araştırmada web sitesinin sıralamasına göre görseller ve metinler içerik bağlamında Alderfer'in ERG teorisindeki ihtiyaçlar kategorisi bağlamında incelenecektir.

\section{İstediğiniz her şey. Ve her şey tam istediğiniz gibi.}

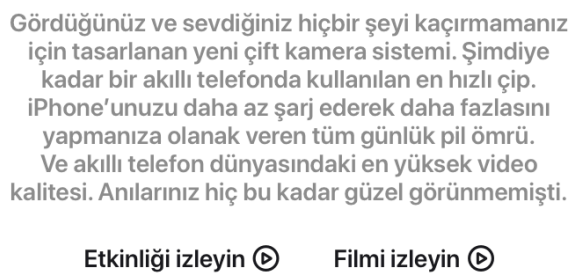

Görsel 1: Iphone 11 web sitesi görseli (Apple, 2020)

Iphone 11 teknik özelliklerinin ve telefonun tanıtıldığ telefonun teknik özellikleri, tüketicinin isteklerinin tamamını karşılayacak bir slogan ile tanıtılmaktadır. Telefon içeriğinde genel olarak kamera özellikleri ön plana çıkartılmaktadır. "Anılarınız hiç bu kadar güzel görünmemişti." Cümlesi ile tüketicinin duygusal güdüleri harekete geçirilmeye çalışılmaktadır. 
iPhone 11

\section{ilk görüşte aşk. İkincide, üçüncüde, dördüncüde, beşincide ve altıncıda da.}

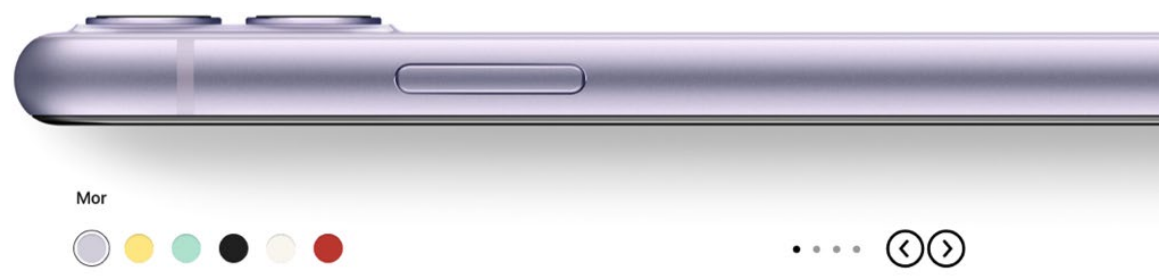

Görsel 2: Iphone 11 Renk skalası (Apple, 2020)

Tüketim kültüründe ürünün, tüketicinin isteğine göre kişiselleştirilmesi ve yaşam tarzını yansıtacak ürünler olmasına önem verilmektedir. Bu bağlamda markalara atfedilen kişisel özelliklerle birlikte markayla tüketici arasında duygusal bir bağ yakalanması hedonik tüketim için önemli bir yapıdır. Bu mekanik sayılabilecek ilişki bağı ERG teorisindeki ilişki kurma bağlamındaki ilişki kurma kategorisinde sevme güdüsünü harekete geçiren bir etken olarak tanımlanabilir. Ayrıca burada, tüketicilerin marka sadakati noktasında güdülenmesi de sağlanmaktadır. Marka sadakati, tüketiciyle marka arasındaki duygusal bağın ulaşabileceği en son noktayı ifade etmektedir. Örneğin; Harley Davidson, Armani, Volkswagen Beetle, Google, Apple, Starbucks, ve Amazon yaptığı iletişim çalışmalarıyla kendilerine oldukça sadık bir tüketici kitlesi elde etmişlerdir (Batı, 2012, s. 117).

iPhone 11

\section{Arkadaş çevreniz kadar geniş.}

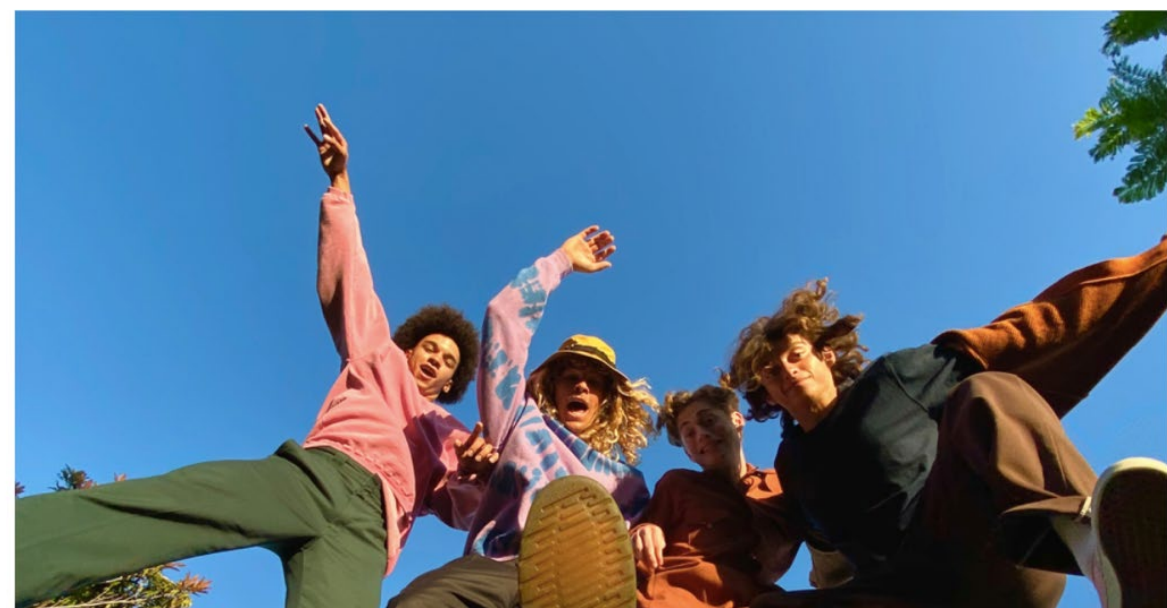

Görsel 3: Iphone 11 kamera özelliği tanıtımı (Apple, 2020) 
Iphone 11'in geniş açılı kamerasının tanıtımı bölümünde tüketicinin sosyal çevresine atıfta bulunulmaktadır. Yine ERG teorisindeki ilişki kurma kategorisi kapsamında değerlendirilebilecek sosyal çevre, aidiyet kavramı üzerinde durularak tüketicinin sosyal çevre ihtiyacı noktasında bir motivasyon süreci oluşturulmaya çalışılmaktadır. Özellikle sosyal medya platformlarında görsel içeriğin kişinin kendisini gerçekleştirme ve sosyal çevresini paylaşma davranışlarından yola çıkılarak tüketicinin satın alma davranışına etki sürecine katkıda bulunulmaktadır. Slogan incelendiğinde telefonun teknik özelliğinden çok hedonik tüketim bağlamında yaşam tarzı reklamcılığı tarzı bir metin içeriğe sahip olduğu da görülmektedir.

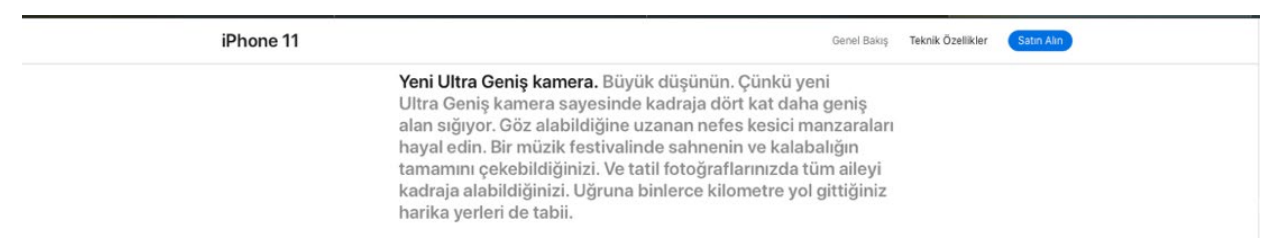

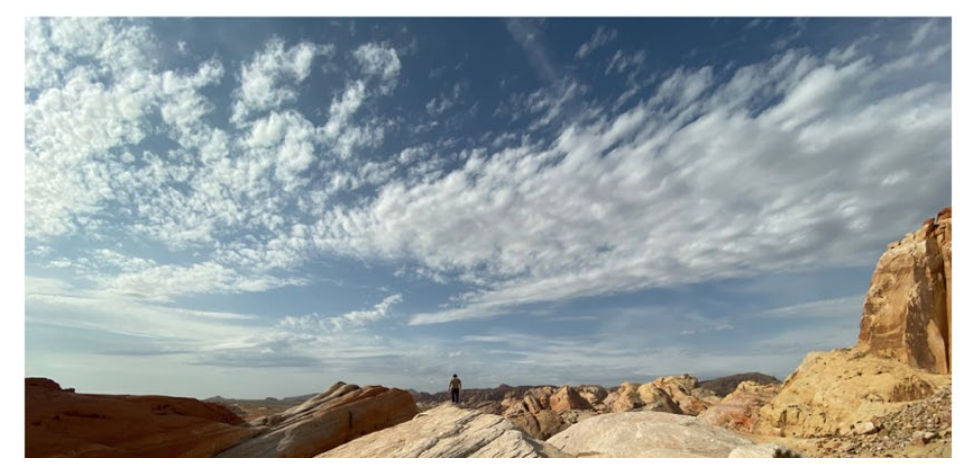

Görsel 4: Iphone 11 kamera özelliği tanıtımı 2 (Apple, 2020)

Iphone 11'de yeni bir özellik olarak sunulan 'Ultra Geniş Kamera" bölümünün alt metninde yer alan ifadeler web sayfasindaki konseptin geneline uygun bir şekilde yaşam tarzı reklamcılığı bağlamında sunulmaktadır. Bölümde teknik özelliklerin yansıtılması yerine "müzik festivali", "tatil", "harika yerler" tanımlamalarıyla tüketiciye yön verilmekte tüketim toplumu çerçevesinde boş zaman etkinlikleri olarak nitelendirilebilecek ve arzu edilecek yerlerle ilgili tüketiciye aksiyona geçirici mesaj verilmektedir. "Hayal edin" cümlesiyle arzu nesnesini ön plana koyan ve hedonik tüketim öğesi olan bu tanıtım metni Alderfer'in Gelişme bölümünde yer alan kendini gerçekleştirme alanında yaratıcılığı ön plana çıkarma ihtiyacına vurgu yapmaktadır. 


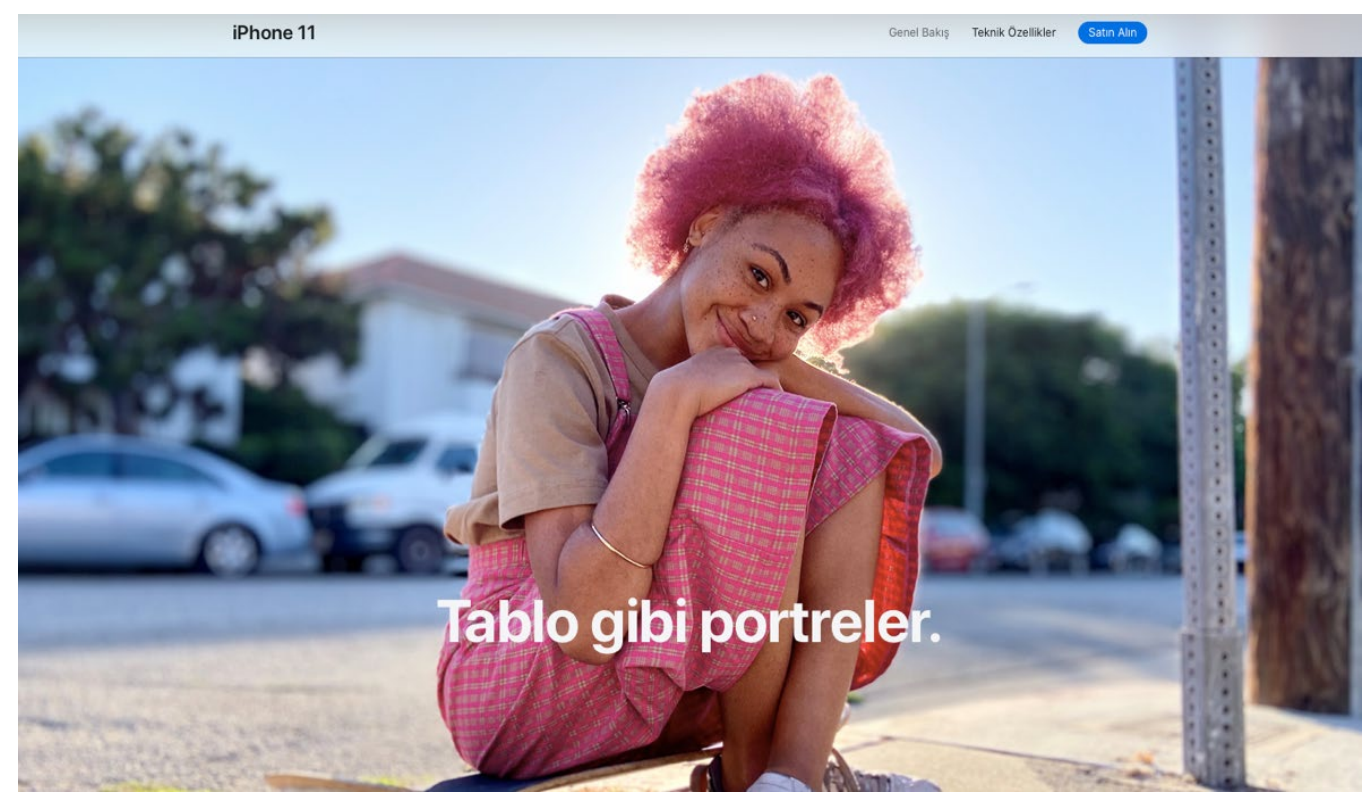

Görsel 5: Iphone 11 kamera ile çekilmiş fotoğraf (Apple, 2020)

iPhone 11

\section{Akıllı HDR.} Şimdi herkes fotojenik.

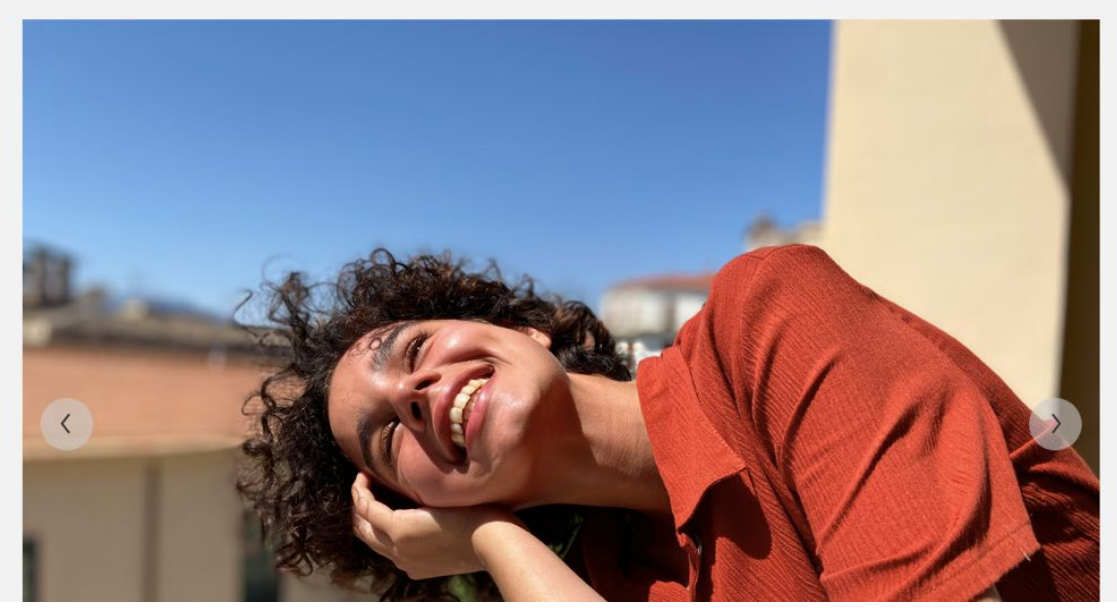

Görsel 6: Iphone 11 kamera özelliği tanıtımı 3 (Apple, 2020)

Görsel 5 ve Görsel 6'da yer alan fotoğraflar ve Görsel 6'daki metin araştırmanın hem ERG teorisi hem de hedonik tüketim kısımları için önemli içerikler sunmaktadır. Hedonik tüketim bağlamında Jean Baudrillard'ın Tüketim Toplumu (2015) kitabında belirttiği gibi beden bir tüketim nesnesi olarak kullanılmaktadır. Buna ilaveten sosyal medya platformlarındaki görsel içeriklerde tüketiciler kendi bedenleri üzerinden paylaşımlarda bulunmaktadırlar. Bu noktada akıllı telefon tercihi yapılırken kamera özelliğinin önemli bir noktada olması telefon tanıtımında kamera özelliklerinin ön plana çıkarılmasını gerektirmektedir. Iphone 11 web sayfası tanıtımında en çok kişisel paylaşım izlenimi veren görsellere yer verildiği tespit edilmiştir. Web sayfasında toplam 24 farklı kişisel paylaşım görseli olarak nitelendirilebilecek görsele yer verilmiş ve bu görsellerde de hedonik tüketimi 
özendirecek sembolik öğeler (arkadaşlık, tatil, klasik otomobil, doğa gezisi) kullanılmıştır. Ayrıca Görsel 5 ve 6'da ERG teorisinin ilişki kurma ve gelişme kategorilerinde yer alan beğenilme güdüsüne vurgu yapılmıştır.

\subsection{Sonuç ve Yorum}

İnsanın motivasyon süreci ve ihtiyaçları bağlamında motive olması psikoloji biliminin araştırma konularından biri olmasına rağmen diğer sosyal bilimler için de oldukça önemli bir konudur. Bu çalışmanın kavramsal çerçevesi de bu yapıya odaklanmış ve bağlam olarak tüketim kültürü içerisinde oluşan sembolik yapıların hedonik tüketime yol açması ve hedonik tüketimin insan/birey/tüketicide hangi durumlarda motivasyon sağladığı Alderfer’in ERG teorisi düzleminde incelenmiştir.

Araştırma konusu olan Iphone 11'in Apple web sitesindeki tanıtım sayfasındaki görsel ve metinsel içeriklerden yola çıkılarak elde edilen sonuçlar ERG teorisine göre incelenmiştir. İhtiyaç kuramlarının içerik/kapsam teorileri kategorisinde yer alan ERG teorisi genellikle iş dünyasında çalışanların motivasyon kaynaklarının anlaşılmasıyla ilgili çalışmaların teorik çerçevesini oluştursa da Maslow'un ihtiyaçlar hiyerarşisi teorisine göre daha esnek olması, sürecin içine çevre ve kültürü dahil etmesi, ihtiyacın belli bir süre karşılanmaması noktasında geri çekilme olgusu ve ihtiyaçların aynı anda ortaya çıkmasıyla birlikte (Örneğin; varoluşsal ihtiyaçların karşılanamaması durumunda gelişme ihtiyacının önem kazanması gibi maddeler içermesi) günümüz tüketici kültürü ve tüketici alışkanlıklarının anlaşılması bağlamında da inceleme ve araştırmalara teorik çerçeve oluşturabilecek bir noktadadır.

Araştırmanın ERG teorisi kısmında yapılan incelemelere bağlı kalınarak ilişki kurma ve gelişme kategorilerindeki ihtiyaçların oluşturduğu motivasyon kaynakları, varoluşsal ihtiyaçlardaki motivasyon kaynaklarından daha önemli görülmektedir. Özellikle sosyal çevre ve beğenilme üzerine hazırlanmış görsel ve metinler bu hipotezi doğrular niteliktedir. Buna ilaveten ihtiyacın belli bir süre karşlanmaması durumunda tatmin edilmiş ihtiyaca yönelme durumu günümüz dünyasında sürekli olarak empoze edilen lüks yaşam bağlamında ele alınabilir bir olgu olarak görülebilir. Bu noktada toplum içinde normal seviyelerde yaşayan bir insanın lüks ihtiyaçlara ulaşamaması noktasında otomobil, ev, değerli aksesuarların satın alınamaması Iphone gibi değerli bir markanın lüks tüketicide de normal tüketicide de bulunmasıyla eşleştirilebilir. Tüketim kültürünün genel yapısıyla düşünüldüğünde ortaya çıkarılabilecek olan bu duruma Iphone 11 web sayfası tanıtımında rastlanmamıştır. Fakat bu noktada Iphone telefonların ürün yerleştirme ve halkla ilişkiler çalışmalarıyla bu süreci destekleyebileceği yönünde hipotezler Iphone'un farklı iletişim çalışmalarının incelenmesiyle ortaya çıkarılabilir.

Çalışmanın ikinci teorik çerçevesi olan hedonik tüketim öğesi bağlamında Iphone 11'in web sayfası tanıtımı incelendiğinde yaşam tarzı reklamcılığ bakımından çalışmalar yapıldığı görülmektedir. Teknik özelliklerden çok harekete geçirici, hayal edilebilecek kavramlar üzerinden oluşturulmuş sloganlar ve görsellere yer verilmiştir. Tüketicinin sembolik/hazcı tüketim algısını harekete geçirecek görseller ve metinlerin ağırlıkta olması çalışmanın bu bağlamda da desteklendiğini ve doğrulandığını göstermektedir. 
Hem ERG teorisi hem de hedonik tüketim bakımından bir markanın tanıtım öğelerinin incelendiği çalışmalarda hedonik tüketim, bireyin kendini gerçekleştirme ve sosyalleştirme ihtiyaçlarına göre reklam çalışmalarına yer vermekte, ERG teorisi de bu bağlamda esnek bir yapı oluşturarak günümüzdeki tüketim anlayışına uygun bir model sunması sebebiyle araştırma kapsamında sorulan sorulara olumlu cevapların alındığı bir çalışmaya teorik çerçeve oluşturmaktadır.

\section{Kaynakça}

Alan, U. (2006). Motivasyon Teorileri ve Motivasyonun İş Hayatı Üzerindeki Etkileri, Yüksek Lisans Tezi. İstanbul: Beykent Üniversitesi Sosyal Bilimler Enstitüsü.

Alderfer, C. (1967). An Organizational Syndrome. Administrative Science Quarterly, 12(3), 440-460.

Anık, C. (2000). Siyasal İkna. Ankara: Vadi Yayınları.

Apple. (2020, Ocak 4). Iphone 11. Apple Türkiye: https://www.apple.com/tr/iphone-11/specs/ adresinden alındı

Ar, A. A. (2004). Marka ve Marka Stratejileri. Ankara: Detay Yayınları.

Arık, İ. A. (1996). Motivasyon ve Heyecana Giriş. İstanbul: Çantay Kitabevi.

Aziz, A. (2011). Sosyal Bilimlerde Araştırma Yöntemleri ve Teknikleri. Ankara: Nobel Yayınları.

Batı, U. (2012). Markethink ya da Farkethink - Deneyimsel Pazarlama ve Duyusal Markalama. İstanbul: Ece Bilişim Yayıncılık Ltd. Şti.

Baudrilard, J. (2015). Tüketim Toplumu - Söylenceleri ve Yapıtları. İstanbul: Ayrıntı Yayınları.

Bilgin, N. (2006). Sosyal Bilimlerde İçerik Analizi Teknikler ve Örnek Çalışmalar. Ankara: Siyasal Kitabevi.

Caulton, J. R. (2012). The Development and Use of the Theory of ERG: A Literature Review. Emerging Leadership Journeys, 5, 2-8.

Efere, P. (2005). Motivation and Job Satisfaction. Trans-Atlantic College, 1-25.

Ergun Özler, N. D. (2013). Güdüleme. C. Koparal , \& İ. Özalp içinde, Yönetim ve Organizasyon (s. 124-159). Eskişehir: Anadolu Üniversitesi.

Featherstone, M. (1996). Postmodernizm ve Tüketim Kültürü. İstanbul: Ayrıntı Yayınları.

Gülbay, F. k. (2016, Ocak 16). Maslow'un İhtiyaçlar Hiyerarşisi. Medium: https://medium.com/türkiye/maslowun-ihtiyaçlar-hiyerarşisi-d3b99924c49 $\mathrm{b}$ adresinden alındı 
Karadoğan Doruk, E. (2015). İknanın Sosyal Psikolojisi Temel Kavramlar ve Kuramlarıyla. İstanbul: Derin Yayınları.

Koçel, T. (2010). İşletme Yöneticiliğii. İstanbul: Beta Yayınları.

Lodziak, C. (2003). İhtiyaçların Manipulasyonu Kapitalizm ve Kultü̈. İstanbul: Çitlembik Yayınları.

Odabaşı, Y. (2013). Tüketim Kültürü. İstanbul: Sistem Yayıncılık.

Türk Dil Kurumu Sözlükleri. (2020, 01 04). Türk Dil Kurumu Sözlükleri: https://sozluk.gov.tr adresinden alındı

Taşdemir, S. (2013). Motivasyon Kavramına Genel Bir Bakış, Motivasyon Araçları ve Bilgi Teknolojileri ve İletişim Kurumu Ölçeğinde Bir Model Önerisi. Ankara: Bilgi Teknolojileri ve İletişim Kurumu.

Ulukuş, K. S. (2016, Mart). Motivasyon Teorileri ve Lider Yöneticilik Unsurlarının Bireylerin Motivasyonuna Etkisi. Akademik Sosyal Araştırmalar Dergisi(25), 247-262.

Us, A. T. (2007). İşletmelerde Motivasyon. İstanbul: İgiad Yayınları.

Uztuğ, F. (2005). Markan Kadar Konuş. İstanbul: Kapital Medya Hizmetleri A.Ş.

Vikipedi. (2021, Ekim 20). Iphone. Vikipedi: https://tr.wikipedia.org/wiki/İPhone adresinden alındı

Vikipedi. (2021, Ağustos 9). Iphone11. Vikipedi: https://tr.wikipedia.org/wiki/IPhone_11 adresinden alındı

Williamson, J. (2001). Reklamların Dili Reklamlarda Anlatım ve Ídeoloji. Ankara: Ütopya Yayınevi. 